\title{
A Study of Benchmarking Influence on Customer Satisfaction
}

\author{
Moayyad Al-Fawaeer \\ Assistant Professor, Department of Administration \\ The World Islamic Sciences \& Education University, Jordan \\ Tel: 962-777-307-411 E-mail: Dr.moayyad@yahoo.com \\ Khaled Bany Hamdan \\ Assistant Professor, Department of Business Administration \\ Applied Science University \\ P.O. Box 166, Amman 11931, Jordan \\ Tel: 962-795-559-444Ｅ-mail: banyhamdan@yahoo.com \\ Hasan Ali Al-Zu'bi \\ Professor, Department of Business Administration \\ Applied Science University \\ P.O. Box 922717, Amman 11192, Jordan
}

Tel: 962-795-629-808Ｅ-mail: zubi1963@yahoo.com

Received: January 17, $2012 \quad$ Accepted: February 27, $2012 \quad$ Published: April 16, 2012

doi:10.5539/ijbm.v7n8p108 URL: http://dx.doi.org/10.5539/ijbm.v7n8p108

\begin{abstract}
This study aims to investigate the influence of benchmarking on the outcomes of customer satisfaction, loyalty within the Jordanian banks.

The study population consists of employees working in them. A simple random sampling technique was used to select the respondents surveyed for this study with a total of 188 questionnaires administered to the chosen respondents.

Statistical tools were used to test the hypothesis. The findings of this study indicate that there is a significant positive influence of benchmarking (Measurement, Comparison, Learning, and Adaptation) on customer satisfaction, the study also shows that customer satisfaction has a significant influence on customer loyalty within these banks.
\end{abstract}

Keywords: Benchmarking, Customer Satisfaction, Loyalty, Jordanian banks

\section{Introduction}

In this age, in which companies operate in an intense competitive atmosphere and further globalization of markets, fundamental changes occurred, and forced many companies to rethink and adapt their strategies to search for new philosophies and innovative management techniques to improve their competitive position.

It is known widely, that benchmarking is one of the most important tools used by business firms for the purpose of achieving continuous improvement in products (goods and services), and this in turn leads to customer satisfaction, which is reflected at the level of loyalty to them and increase in profits.

Benchmarking is a technique aligned with the company's mission, goals, and objectives. A misalignment of benchmarking with the corporate strategy and customer values can lead to the optimization of processes that add little to the company or to customer satisfaction. Benchmarking is process based on customer values as well as on the strategy of the company (Gannaway, 1996).

However, given formalization of benchmarking as an instrument for practice management, and use a wide range 
of companies within the instruments of change in the completion of business processes. We believe that by the Xerox Corporation in 1980, was a leading sales of imaging machines, and to remain the market leader, it needs to change its approach to business and focus on its customers (Deros \& et al, 1999). Formal definitions of benchmarking often differ between companies, Xerox; a pioneer in competitive benchmarking defines it as: The continuous process of measuring products, services, and practices against the toughest competitors or those companies recognized as industry leaders (Sadeghi, 1999).

In Jordan, the banking sector contributes a large proportion towards the gross domestic product. These banks influence the financial service industry's use of important tools, such as benchmarking, to improve the level of banking services provided to customers, this also benefits the development of excellence of their services, in addition to increasing the level of customers' loyalty and profits.

\section{Literature review}

\subsection{Benchmarking}

Benchmarking was initially developed as a total quality management tool by Xerox in 1979. Since then, it has been widely adopted by manufacturing and service industries, and other industries around the world (Camp, 1989). Benchmarking has defined the companies or industry's best practices that will lead to superior performance or organizational success (Chi Lai, et al., 2011). It's a significant tool to shape organization strategy and reaching a potential competitive advantage. Therefore, benchmarking has been an increasingly important performance management tool that can be used to enable managers to both monitor and improve aspects of their own operational performance by reference to, and learning from, other organizations (Francis, et al., 2002). The aim of benchmarking is to focus on learning from outstanding organizations to find ways to trim costs and delays and to improve customer satisfaction.

There are four types of benchmarking that analysts agree on, including internal benchmarking, competitive benchmarking, functional or industry benchmarking, and generic benchmarking (Elmuti, 1997, Chi Lai, et, al., 2011). The main themes in benchmarking include performance measurement, comparison, identification of best practices and improvement (Geelings et, al., 2006). Benchmarking is useful not only for large corporations, but small and medium size companies can reap the benefits of benchmarking as well.

Typically measures used in benchmarking include cost per unit, service upsets (breakdowns) per customer, revenue per unit, return on investment and customer satisfaction levels (Krajewski, 2010).

\subsection{Customer Satisfaction and Outcomes of Satisfaction}

In this section the research highlights the relevant literature on the concept of satisfaction, and its consequences (loyalty).

\subsubsection{Satisfaction}

Satisfaction has been considered as one of the most important theoretical as well as practical issue for most marketers and customer researchers (Jamal, 2004). Oliver (1981, p. 29) firstly defined it in the consumption context as "the summary psychological state resulting when the emotion surrounding disconfirmed expectations is coupled with the customer's prior feelings about the consumption experience". In other words, we may say that satisfaction reflects a post-purchase evaluation of product quality given pre-purchase expectations (Kotler, 1991).

On one hand, within literature on services marketing, satisfaction has traditionally been defined as a cognitive-based phenomenon (Westbrook, 1987). Cognition has been studied mainly in terms of the expectations /disconfirmation paradigm; also known as the confirmation/disconfirmation paradigm, which states that expectations originate from the customer's beliefs about the level of performance that a product/service would provide (Oliver, 1980). Many marketing scholars (Tse and Wilton, 1988; Anderson and Sullivan, 1993; Patterson et al, 1997), indicate that customer satisfaction is related to the size and direction of disconfirmation, which is defined as the difference between the post-purchase and post-usage evaluation of the performance of the product/service and the expectations held prior to the purchase (Sharma and Ojha, 2004).

On the other hand, other studies (Dube-Rioux, 1990; Homburg et al, 2006) have recognized that the affect experienced during the acquisition and consumption of the product or service can also have a significant influence on satisfaction judgments (Homburg et al, 2006). Dube-Rioux (1990) points out that a consumer affective response can be used to predict satisfaction more accurately than cognitive evaluation. Therefore, it is hypothesized that customer satisfaction has positive impact on customer loyalty. 


\subsubsection{Loyalty}

Oliver (1999, p. 34) defines loyalty as "a deeply held commitment to re-buy or re patronize a preferred product/service consistently in the future, thereby causing repetitive same brand or same brand-set purchasing, despite situational influences and marketing efforts having the potential to cause switching behavior". Broadly, loyalty development has been an objective traditionally aimed at by managers (Andreassen, 1999) since it enables higher future purchase intention. In particular, loyalty may be defined as a customer's intention or predisposition to purchase from the same organization again (Edvardsson et al, 2000), that result from the conviction that the value received from one seller is greater than the value available from other alternatives (Hallowell, 1996). As a consequence, loyalty has been considered to be a key factor in order to achieve company success and sustainability over time (Flavián et al, 2006; Keating et al, 2003).

\section{The objectives of the Research}

The research objectives are to build and test a suggested model that supports the benchmarking influence on customer satisfaction. We try to test the suggested model at the Jordanian banks. And here are some more objectives related to the statement of the research:

1) To examine the influence of benchmarking on customer satisfaction.

2) To examine the influence of customer satisfaction on outcomes of satisfaction (loyalty).

\section{Suggested model}

A model consists of two types of variables, the independent variable (benchmarking) and the dependent variable (outcomes of customer satisfaction) as shown in figure (1).

\section{Research Hypotheses}

In order to achieve the research objectives, the following main hypotheses and their sub-hypotheses are developed for testing:

Hypothesis 1: There is no significant influence of Benchmarking dimensions on Customer Satisfaction.

Hypothesis 1-a: There is no significant influence of Measurement on Customer Satisfaction.

Hypothesis 1-b: There is no significant influence of Comparison on Customer Satisfaction.

Hypothesis 1-c: There is no significant influence of Learning on Customer Satisfaction.

Hypothesis 1-d: There is no significant influence of Adaptation on Customer Satisfaction.

Hypothesis 2: There is no significant influence of Customer Satisfaction on Loyalty.

\section{Methodology}

\subsection{Data and Sample}

To gather data for this study, a random sample of (200) employees was selected from the population of Jordanian banks. Of the (193) questionnaires returned, (5) were rejected due to incomplete responses and (188) responses (percent response rate) were used for data analyses.

It should be noted that every questionnaire was personally handed and instructions were given to each employee before completing the questionnaire. In terms of demographic findings, (\%65) of respondents were males, and the remaining (\%35) were females. In terms of the age group of respondents, it is interested to note that (\%7) of them are less than (26) years, whereas (\%15) fell into the (26-30) age group, whereas (\%16) fell into the (31-35) age group, whereas (\%26) fell into the (36-40) age group, whereas (\%27) fell into the (41-45) age group only $(\% 9)$ are above this group. As for the educational levels of these employees, the majority (\%74) were university certificate holders, and some those (\%14) of these, have Higher Education degree. See table (1).

\subsection{Research Instrument}

Benchmarking variables which include: Measurement, Comparison, Learning and Adaptation (Ateani, 2009).

Customer Satisfaction variables which include: Satisfaction and Loyalty (Ahmad \& Al-Zu'bi, 2011).

\subsection{Instrument validity and reliability}

\subsubsection{Instrument validity}

The content validity of the questionnaire was determined by a panel of experts in the fields of, Benchmarking, and Customer Satisfaction. 


\subsubsection{Instrument reliability}

The reliability of the survey instrument was assessed through Cronbach's coefficient alpha (a). All coefficients alpha were within acceptable ranges for comparable instruments (Sekran, 2006).

\section{Results and Discussion}

Our basic assumptions are that Benchmarking dimensions namely (Measurement, Comparison, Learning and Adaptation) influence Customer satisfaction and outcomes of satisfaction namely loyalty.

\subsection{The Benchmarking dimensions has a positive significant influence on customer satisfaction}

The strength of the proposed influence was assessed using the respective statistical analyses summarized in Tables 2 .

The results of this study show that the influence of Measurement on the customer satisfaction is significant. The multiple regression result shows Measurement has beta $=0.223$, $\mathrm{t}$-value $=4.495$, $\mathrm{p}$-value $=0.000$. The results prove that, the null hypothesis that there is no significant influence of Measurement on Customer satisfaction the can be rejected.

In this situation, the employees who are working in Jordanian banks perceived Measurement an important factor for Customer satisfaction.

Comparison is one of the dimensions that would encourage staff to Benchmarking with each other in the Banks. Results of this study show that there is an influence of the compliment on the Customer satisfaction. The regression result (beta $=0.349, \mathrm{t}$-value $=6.361, \mathrm{p}$-value $=0.000$ ) indicates that the influence of Comparison on Customer satisfaction is significant at $(0.01)$ level $(p$-value $=0.024)$. The result shows that there is a positive direction between the two constructs. Accordingly, the hypothesis is rejected $1-b$.

Researches have investigated the importance of Learning. It is one of the main dimensions that make Benchmarking successful in a Banks. Learning dimension is an important dimension that has a positive influence on the Customer satisfaction. Referring to Table 3, the 1-c hypothesis tested the no significant influence of Learning on the Customer satisfaction. The regression result (beta $=0.531, t-v a l u e=9.336,(p-v a l u e=0.000)$ indicates that the influence of Learning on the Customer satisfaction is significant at 0.01 level ( $\mathrm{p}$-value $=0.000$ ). In term of direction, the result shows that there is a positive direction between the two constructs.

The results of this study show that the influence of Adaptation on the Customer satisfaction is significant at 0.01 level. The multiple regression result shows Adaptation has beta $=0.421 ; \mathrm{t}$-value $=5.065$ ( $\mathrm{p}$-value $=0.000)$. The results prove that, the null hypothesis that there is no significant influence of Adaptation on the Customer satisfaction can be rejected.

In this situation, the employees who are working in Jordanian banks perceived Adaptation as important dimension for Customer satisfaction.

The results of this study show that the influence of customer satisfaction on Loyalty is significant. The simple regression result shows customer satisfaction has beta $=0.632, \mathrm{t}$-value $=11.109,(\mathrm{p}$-value $=0.000)$. The results prove that, the null hypothesis that there is no significant influence of customer satisfaction on the Loyalty can be rejected, See table 3.

From the above results, we can say that the objectives of the study have been achieved, for the first objective the results indicate that there is a good influence of all the dimensions of Benchmarking on Customer satisfaction in the Jordanian Banks. As for the second objective, customer satisfaction to achieve the Loyalty in the Jordanian Banks.

\section{Conclusion}

This research seeks to make an original contribution to knowledge by investigating the influence of Benchmarking on outcomes of customer satisfaction in the banks services industry in Jordan. It contributes to the management discipline in finding out the role of the Benchmarking enhancing customer satisfaction and loyalty.

Dimensions pertaining to Measurement, Comparison, Learning and Adaptation were the focus of this study as they have an influence on customer satisfaction.

Contributions found will be beneficial for both academics and managers alike. Academically, this work aims to focus academic attention upon a much neglected domain - the operations management of banking services in Jordan. There is currently a distinct lack of studies in academia relating to research in the Middle East. This is somewhat surprising when considering that Jordan has been at the forefront of the banking services industry in the Middle East. 
In fact, the banking services industry is an important and vibrant sector in Jordan and banks are considered as an important segment of the financial services provider where customers can receive a wide range of financial services.

Although this research has provided valuable insights into a somewhat scant area of research, it has been subject to some limitations. To begin with, this research has been conducted within a single service industry and exclusively in the Jordanian commercial banks sector, thus limiting the generalisability of the research results to the foreign banks and other financial organizations in Jordan.

Future research is therefore required to extend these results in other geographical areas. For example, the concept could be extended to other Arab countries in order to validate the model and findings. By studying other service and financial services (for example, money transfer services, insurance companies) a model could be developed to better represent the service sector in more general, rather than focusing on the commercial banks alone. The inclusion of employees at all service levels would allow for more insight to be gathered on employees' viewpoints, attitudes, perceptions and overall satisfaction of outcomes of satisfaction.

\section{Study Limitations}

This study has several limitations. The first limitation of this study is that Personal bias: some of the information in this study reflects the judgment of individuals who provided the information and may have biases favoring the success of their companies.

The second limitation of this study is the lack of sufficient levels of data, the reason behind that is that many companies look at the data as confidential.

\section{Recommendations for future research}

Future research is therefore required to extend these results in other geographical areas. For example, the concept could be extended to other Arab countries in order to validate the model and findings.

Future research should also investigate whether the model could be used for a comparative study between the service sector and the industrial sector. By doing so, it would be interesting to test whether the model could hold across a range of industries and service sectors apart from banking industry.

This study also suggests more research is needed to examine the relationship between benchmarking and other variables, such as quality.

\section{References}

Ahmad, A. Khalaf., \& Al-Zu'bi, H. A. (2011). E-banking functionality and outcomes of customer satisfaction: an empirical investigation. International Journal of Marketing Studies, 3(1), 50-65.

Anderson, E. W., \& Sullivan, M. W. (1993). The antecedents and consequences of customer satisfaction for firms. Marketing Science, 12(2), 125-43. http://dx.doi.org/10.1287/mksc.12.2.125

Andreassen, T. W. (1999). What drives customer loyalty with complaint resolution?. Journal of Service Research, 1(4), 324-32. http://dx.doi.org/10.1177/109467059914004

Ateani, M. Saleem. (2009). The benchmarking in improving institutional performance of the Jordan pharmaceutical firms. Dissertation, The Arab Academy for Banking and Financial Sciences, Jordan.

Camp, C. (1989). Benchmarking: The search for the industry Best Practice that Leads to Superior Performance. Milkwaukee, WI: ASQC Quality Press.

Chi Lai, M., Wang, W., \& Huang, H. (2011). Linking the benchmarking tool to a knowledge-based system for performance improvement. Expert Systems with Applications, 38(8), 10579-10586. http://dx.doi.org/10.1016/j.eswa.2011.02.101

Deros, B. Md., Nor Kamaliana Khamis., Mohd Nizam Ab R., \& Ahmad Rasdan Ismail. (2009). A Survey on benchmarking understanding and knowledge among Malaysian automotive components manufacturing SMEs. European Journal of Scientific research, 33(3), 385-397.

Dube-Rioux, L. (1990). Power of affective reports in predicting satisfaction judgments. In Goldberg, M., Gorn, G.,Pollay, R. (Eds.), Advances in Consumer Research, 17, 571-6.

Edvardsson, B., Johnson, M. D., Gustafsson, A., \& Strandvik, T. (2000). The effects of satisfaction and loyalty on profits and growth: products versus services. Total Quality Management, 11, 917-27. http://dx.doi.org/10.1080/09544120050135461 
Elmuti, D., Kathawalay Y., \& Lioyed, S. (1997). The benchmarking process: Assessing its value and limitations. Industrial Management, 39(4), 12-19.

Flavián, C., Guinalíu, M., \& Gurrea, R. (2006). The role played by perceived usability, satisfaction and consumer trust on website loyalty. Information \& Management, 43(1), 1-14. http://dx.doi.org/10.1016/j.im.2005.01.002

Francis, G., Humphreys, I., \& Jackie, F. (2002). The benchmarking of airport performance. Journal of Air Transport Management, 8(4), 239-247. http://dx.doi.org/10.1016/S0969-6997(02)00003-0

Gannaway, J. Neil. (1996). Analysis of the benchmarking process as a potential tool to enhance organizational competitiveness. Dissertation, Methodist University, USA.

Geerlings, H., Klementschitz, R., \& Mulley, C. (2006). Development of a methodology for benchmarking public transportation organizations: a practical tool based on an industry sound methodology. Journal of Cleaner Production, 14, 113-123. http://dx.doi.org/10.1016/j.jclepro.2005.03.021

Hallowell, R. (1996). The relationships of customer satisfaction, customer loyalty, and profitability: an empirical study. International Journal of Service Industry Management, 7(4), 27-42. http://dx.doi.org/10.1108/09564239610129931

Homburg, C., Koschate, N., \& Hoyer, W. D. (2006). The role of cognition and affect in the formation of customer satisfaction: a dynamic perspective. Journal of Marketing, 70(July), 21-31. http://dx.doi.org/10.1509/jmkg.70.3.21

Jamal, A. (2004). Retail banking and customer behavior: a study of self concept, satisfaction and technology usage. The International Review of Retail, Distribution and Consumer Research, 14(3), 357-379. http://dx.doi.org/10.1080/09593960410001678381

Keating, B., Rugimbana, R., \& Quazi, A. (2003). Differentiating between service quality and relationship quality in cyberspace. Managing Service Quality, 13, (3), 217-32.http://dx.doi.org/10.1108/09604520310476481

Kotler, P. (1991). Marketing Management: Analysis, Planning, Implementation, and Control. (7th ed.). USA: Prentice-hall.

Krajewski, L., Ritzman, L., \& Malhotra, M. (2010). Operational Management: Process and Supply Chains. (9th ed.). Pearson Education, Saddle River, New Jersey.

Oliver, R. L. (1999). Whence consumer loyalty?. Journal of Marketing, 63, 33-44. http://dx.doi.org/10.2307/1252099

Oliver, Richard, L. (1980). A Cognitive Model of the Antecedents and Consequences of Satisfaction Decisions. Journal of Marketing Research, 17(September), 460-469. http://dx.doi.org/10.2307/3150499

Oliver, Richard, L. (1981). Measurement and Evaluation of Satisfaction Process in Retail Setting. Journal of Retailing, 57(Fall), 25-48.

Patterson, P. G., Johnson, L.W., \& Spreng, R. A. (1997). Modeling the determinants of customer satisfaction for business-to-business professional services. Journal of the Academy of Marketing Science, 25(1), 4-17. http://dx.doi.org/10.1007/BF02894505

Sadeghi, Afshan. (1999). An empirical model for development and implementation of benchmarking. Dissertation, University of Missouri - Rulla, USA.

Sharma, N., \& Ojha, S. (2004). Measuring service performance in mobile communication. The Service Industries Journal, 24(6), 109-28. http://dx.doi.org/10.1080/0264206042000299202

Tse, D. K., \& Wilton, P. C. (1988). Models of customer satisfaction formation: an extension. Journal of Marketing Research, 25(2), 204-12. http://dx.doi.org/10.2307/3172652

Westbrook, R. A. (1987). Product/consumption-based affective responses and post-purchase processes. Journal of Marketing Research, 24(3), 258-70. http://dx.doi.org/10.2307/3151636 
Table 1. Characteristics of the Sample $(\mathrm{N}=179)$

\begin{tabular}{|c|c|c|}
\hline Characteristics & Frequency & Percent \\
\hline \multicolumn{3}{|l|}{ Gender: } \\
\hline Male & 123 & 0.65 \\
\hline Female & 65 & 0.35 \\
\hline \multicolumn{3}{|l|}{ Age: } \\
\hline$<26$ & 13 & 0.07 \\
\hline $26-30$ & 29 & 0.15 \\
\hline $31-35$ & 30 & 0.16 \\
\hline $36-40$ & 49 & 0.26 \\
\hline $41-45$ & 51 & 0.27 \\
\hline$>45$ & 16 & 0.09 \\
\hline \multicolumn{3}{|l|}{ Education level: } \\
\hline High School or Less & 4 & 0.02 \\
\hline Community College Diploma & 19 & 0.10 \\
\hline Bachelor & 139 & 0.74 \\
\hline Postgraduate & 26 & 0.14 \\
\hline
\end{tabular}

Table 2. Multiple Regression Results

\begin{tabular}{|l|c|c|c|}
\hline \multicolumn{1}{|c|}{ Variables } & Beta & t-value & p-value \\
\hline Measurement & 0.223 & 4.495 & 0.000 \\
\hline Comparison & 0.349 & 6.361 & 0.000 \\
\hline Learning & 0.531 & 9.336 & 0.000 \\
\hline Adaptation & 0.421 & 5.065 & 0.000 \\
\hline
\end{tabular}

Table 3. Simple Regression Results

\begin{tabular}{|c|c|c|c|}
\hline Variables & Beta & t-value & p-value \\
\hline Loyalty & 0.632 & 11.109 & 0.000 \\
\hline
\end{tabular}

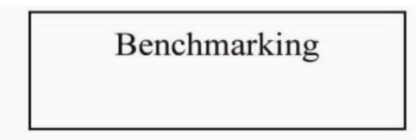

Outcomes of customer satisfaction

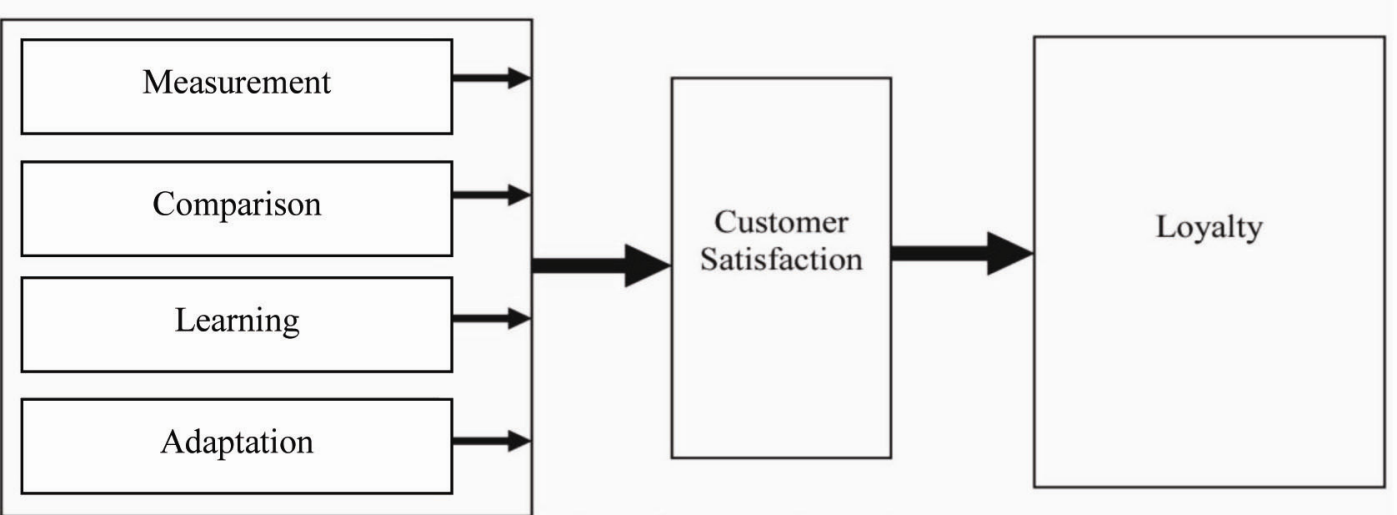

Figure1. Research Model 